\title{
Stock Market Development and Economic Growth in Belgium
}

\author{
Stijn Van Nieuwerburgh* \\ New York University Stern School of Business
}

Frans Buelens

University of Antwerp

Ludo Cuyvers

University of Antwerp

July 5, 2005

${ }^{*}$ First version February 2001. Correspondence: svnieuwe@stern.nyu.edu. Stern School of Business Suite 9-120, 44 West Fourth Street, New York, NY 10012. The first author acknowledges financial support from the Flanders Fund for Scientific Research. The second author acknowledges support from GOA-BOF. The authors thank the SCOB for the provision of data. The authors thank Jan Annaert, Marc De Ceuster, Avner Greif, Laura Veldkamp, and Hans Willems and the participants of the University of Antwerp (UFSIA) economics seminar for comments. We also thank Steven Cappoen of the National Bank of Belgium for data on credit institutions. All remaining errors are our own. 


\begin{abstract}
This paper investigates the long-term relationship between financial market development and economic development in Belgium. We use a new data set of stock market development indicators to argue that financial market development substantially affected economic growth. We find strong evidence that stock market development caused economic growth in Belgium, especially in the period between 1873 and 1935. Institutional changes affecting the stock exchange explain the time-varying nature of the link between stock market development and economic growth.
\end{abstract}




\section{Introduction}

The deepening and level of sophistication of modern financial markets is arguably a recent phenomenon. However, stock markets have long played an important role in economic life. DeClercq (1992) describes the early history of the financial system in Belgium, starting in the 14th century. This paper studies the importance of the Brussels stock market for fostering economic growth in the nineteenth and twentieth centuries.

Hicks (1969) argues that in the nineteenth century, for the first time in history, many private investment projects were so large that they could no longer be financed by individuals or from retained profits. The technological inventions of the industrial revolution, such as steam engine, had been made before, but their implementation had to wait for well developed financial markets. The industrial society required an adapted financial system where publicly traded companies could get long-term financing. ${ }^{1}$

Against this background, the Brussels stock exchange opened in 1801 under the Napoleonic occupation (1795-1815). It was the beginning of a period of rapid industrialization. ${ }^{2}$ The spinning jenny was smuggled from England in 1799 and Cockerill imported the new techniques for the iron and steel industry in 1807. The Dutch government of William I (1815-1830) further revived the entrepreneurial spirit in Belgium. Our analysis starts at the beginning of the independence of Belgium in 1830. It focusses on the development and deepening of the Brussels stock exchange and on its growth-promoting role in the next 170 years.

Linking historical evidence to the role of the stock exchange for economic growth requires a theoretical framework. We draw on the functional approach of Levine (1997). Financial markets allow for more efficient financing of private and public investment projects. By representing ownership of large-value, indivisible physical assets by easily tradeable and divisible financial assets, and making trade in them more liquid, they promote the efficient allocation of capital. They give lenders the opportunity to diversify their investments. In these roles, financial markets increase the quality and quantity of intermediated funds. Using descriptive historical evidence, we describe how the Brussels' stock exchange fulfilled these roles.

Our main contribution is to quantitatively assess the role of finance for growth in Belgium post 1830. Using a new data set on indicators of stock market development of the Brussels' stock exchange, we find evidence that financial development significantly contributed to economic growth. Using cointegration analysis, we argue that the rapid expansion of industrial production was not only substantially facilitated, but even driven, by the financial development. Our econometric

\footnotetext{
${ }^{1}$ There has been a lengthy debate on why the Industrial Revolution first started in England and why in the second half of the 18th century (Crafts (1995)). One often heard argument is that Both the Bank of England and the dominant stock market of London gave England a competitive edge.

${ }^{2}$ Belgium was the first country on the European continent to industrialize. France was immersed in its revolution until 1848; and Germany had to wait for its reunification in 1870 before industrial development took hold.
} 
analysis finds evidence of an important long-term relationship between stock market development and economic growth in Belgium, especially in the period of rapid industrialization. The legal liberalization of the stock market in 1867-1873 increased the importance of the stock market. A reversal to more oppressive legislation in 1935 led to the opposite. We not only link the importance of the stock market to economic growth over time, we also interpret it in relationship to the universal banking system. We find that the banking system was more important for economic growth before 1873 than after 1873 , when the stock market took over this role.

The remainder of the paper is organized as follows. In section 2 we review the theoretical finance-growth nexus, with an emphasis on the role of the stock market. Section 3 places our paper in the large empirical literature that has linked financial development to economic growth. In section 4 we describe our data set. Section 5 documents the historical context and the legislative character governing the stock exchange. The main results on the quantitative link between stock market development and economic growth are in section 6 . Section 7 concludes.

\section{Financial Factors in Economic Growth: The Theoretical Nexus}

Why is it that financial development can spur economic growth? In a frictionless ArrowDebreu world there is no room for financial intermediation. Explaining the role played by stock markets or banks requires building in frictions such as informational or transaction costs into the theory. Different frictions motivate different types of financial contracts, markets and institutions. The functional approach of Levine (1997) provides a useful framework to think about the role of financial intermediaries. They perform five interrelated functions. Each of these financial functions can increase growth through two channels: capital accumulation and technological innovation. We briefly review the functions and illustrate them for the case of Belgium in the remainder of the paper.

First, financial intermediaries facilitate pooling and trading of risk. Without financial markets, investors facing liquidity shocks are forced to withdraw funds invested in long-term investment projects. Early withdrawal reduces economic growth. Stock markets can improve upon the situation by giving lenders immediate access to their funds while simultaneously offering borrowers a long-term supply of capital. At the aggregate level, the liquidity risk that individual investors face is perfectly diversified (see Diamond and Dybvig (1983), Greenwood and Smith (1997), Bencivenga and Smith (1991)). Investors also want to diversify productivity risk associated with individual investment projects. Without financial markets they would have to buy entire pieces of capital. Stock markets allow investors to hold a small share in a large number of firms. By facilitating diversification, financial intermediaries allow the economy to invest relatively more in the risky productive technology. This spurs economic growth (see Obstfeld (1994)). 
Second, financial intermediaries improve on the allocation of funds over investment projects by acquiring information ex-ante. Information asymmetries generate a need for prospective research: firms with productive investment projects but no funding have an informational advantage about the quality of their investment. It is difficult and costly for individual investors to screen projects and their managers. Information acquisition costs create incentives for intermediaries to arise: The economy avoids duplication of the screening cost. In the models of (Diamond (1984) and Boyd and Prescott (1986)), investors elect amongst themselves an intermediary who devotes his labor endowment to prospective research for good investment opportunities. Stock markets also play this role. But because information is incorporated in the posted price, the incentives for stock market participants to acquire information may be weaker. However, as stock markets become more liquid and larger it may become easier for investors to disguise their information and this creates an incentive to collect more information. The net result of these two forces is an empirical matter (see Stiglitz (1985) and Levine (1997)).

Third, ex-post monitoring of management and exertion of corporate control also induces the need for financial intermediaries. This is the focus of the costly state verification literature (see Williamson (1986)). The monitor need not be monitored when his asset holdings are perfectly diversified (see Diamond (1984)). Stock markets promote better corporate control. Equity capital introduces a new possibility of aligning interests between the management and the ownership of the firm. Carlos and Nicholas (1990) argue that partial compensation in company stocks mitigated the severe principal-agent problems plaguing the Hudson Bay Company. The relationship is nonmonotonic. As the number of shareholders with voting rights increases, the diffuse ownership makes corporate control more difficult.

Fourth, financial markets mobilize savings in an efficient way. Stock markets establish a market place where investors feel comfortable to relinquish control of their savings. Because securities are in small denominations, a larger fraction of the population can participate in the stock market.

Fifth, financial markets increase specialization. Increased specialization requires lower transaction costs. Townsend (1979) argues that the formation of capital markets takes place endogenously once the economy reaches a threshold per capita income. By reducing financial transaction costs, these capital markets stimulate specialization in the economy and hence growth. In equilibrium there will be efficiently provided financial services.

One feature sets equity markets apart from other financial intermediaries. Equity funding is a fundamentally different contractual agreement from bank credit and corporate debt in that it makes repayment contingent upon performance. This stimulates economic activity both at the intensive (increase in scale) and extensive margin (new firms) by being less binding in bad times. 


\section{Previous Empirical Findings}

Recent economic and econometric research has found quantitative evidence documenting the link between financial development and economic growth. This body of research consists of crosscountry studies and time series studies for single countries. Here we briefly review the findings. There is only limited time series evidence that documents the finance-growth link, and this is what we attempt to do for Belgium in this essay.

\subsection{Cross-country Econometric Evidence}

There is substantial cross-country evidence that countries with a better-developed stock market and banking system witness higher subsequent growth. Most studies focus on the postwar era.

The idea that finance matters for growth in the early stages of economic development goes back to Patrick (1966), Cameron (1967) and Goldsmith (1969). In his study, Goldsmith (1969) establishes the important stylized fact that periods of above average rates of economic growth tend to be accompanied by faster financial development. King and Levine (1993) document a robust relationship between initial levels of financial development and subsequent economic growth across 80 countries, after controlling for other growth-inducing factors. Their measures of financial development are based on the degree of monetization and bank development. Rousseau and Sylla (2001) also employ a cross-country regression framework to make the case for finance-led growth. They use a long data set (1850-1997) for the US, the UK, Japan, France, Germany, and the Netherlands. Consistent with our findings, they argue that financial factors had the strongest effect in the 80 years prior to the Great depression.

Levine and Zervos (1998) conduct a similar analysis for 48 countries and for the period 19761993, but focus on the role played by the stock market. They measure stock market development along various dimensions: size, liquidity, international integration and volatility. More precisely their measures are aggregate stock market capitalization to GDP and the number of listed firms (size), domestic turnover and value traded (liquidity), integration with world capital markets, and the standard deviation of monthly stock returns (volatility). The results suggest a strong and statistically significant relationship between initial stock market development and subsequent economic growth. Including stock market liquidity, stock market capitalization and bank intermediation jointly as regressors yields a separate and significant influence on the rate of economic growth for each of them. This suggests that banks and stock markets play somewhat different roles in the process of economic development. We will return to this issue for the case of Belgium. In a somewhat different sample, Atje and Jovanovic (1993) find that stock market development has a greater effect than bank development on subsequent growth rates.

Rousseau and Wachtel (2000) add a time dimension, and study the link between equity markets 
and growth for 47 countries between 1980-1995 in a dynamic panel setting. They emphasize the importance of the liquidity of stock markets for economic growth.

The relationship between finance and growth in this kind of studies is mainly the result of the inclusion of non-OECD countries. This is consistent with the hypothesis that finance matters for growth mainly in the early stages of development (Gregorio and Guidotti (1995)). There are two objections to this strain of literature. The first is that regression analysis measures correlation between variables, not causality. A cointegration analysis is the more natural setting for causality inferences. The second is that the time series used are often non-stationary. Often, the necessary corrections are not made, which may give rise to spurious correlation.

\subsection{Time-series Econometric Evidence}

We use a cointegration analysis to investigate the direction of causality between financial development and economic growth. The analysis recognizes the non-stationarity of the time series. Cointegration analysis is capable of analyzing both short-run dynamics and common long-run trend movements among the variables in question. Even if individual time series are non-stationary, there may exist a stationary linear combination, a joint trend. They are said to be cointegrated. A long run relationship between finance and growth is present when there exists at least one cointegration vector in a model including GDP and one or more financial development variables. To conclude that finance leads growth, the financial development variables have to be weakly exogenous in the long run. The strength of the analysis is that all variables are endogenous ex-ante.

Hansson and Jonung (1997) investigate the case of Sweden from 1830 to 1991. In a bivariate system, they find that bank development is cointegrated with per capita GDP for the entire period 1834-1991, but the relationship is unstable over time. Banking has the strongest influence on the real economy in the interval 1890-1939 and to a lesser extent in the period 1834-1890.

Rousseau and Wachtel (1998) compare the US, the UK, Canada, Norway and Sweden for the period 1870-1929. This comparative 5 country study uses the same methodology to study tri-variate systems of GDP, the monetary base and financial intensity, measured by the value of the financial sector's assets. The authors find a single cointegration relationship between the three variables under examination, suggesting persistent co-movements between finance and growth.

Demetriades and Hussein (1996) and VanNieuwerburgh (1998) apply cointegration analysis to a mixed sample of developing and developed countries for the postwar era. Financial development variables, which are bank-based, are cointegrated with economic development. In both studies, the direction of causality varies across countries and depends on the measure of financial development used.

The only other papers that investigates the role of the stock market in a cointegration framework are Arestis, Demetriades and Luintel (2001) and Rousseau and Sylla (2005). The former use data 
for Germany, the US, Japan, France and the UK, but their sample only spans the last 25 years. The evidence for finance-led growth is mixed across countries, maybe due to the short sample. Rousseau and Sylla (2005) focus instead on the early stages of economic growth in the U.S. (1790-1850). They convincingly argue that financial development had a significant impact on business incorporations and investment.

On balance, there is evidence in favor of a positive first order causal relationship between bank development and growth. However, the finance-growth nexus is often not unambiguously uni-directional. Time series reveal that causality often works in both directions. Therefore, an important factor in solving the causality question is to pay close attention to historical detail in evaluating the data. This is what we attempt to do for Belgium in section 5 that immediately follows the quantitative results in section 6 . The main strength of our approach then is to interpret the time-series evidence from a historical perspective.

\section{Data}

We build a data set on financial development indicators for Belgium. We use annual data for 1830-2000 from a new, rich database for the Brussels stock exchange (BXS), described in Annaert, Buelens, Cuyvers, Ceuster, Devos, Gemis, Smedt and Paredaens (1998). Most of the series we use are constructed from firm-level data, previously unavailable for Belgium (or for most other countries).

\subsection{Stock Market Development}

Stock market development is measured by the total market capitalization on the BXS. We define five categories of stocks listed on the BXS:

- Category 1: Belgian companies whose main economic activity is located in Belgium.

- Category 2: Foreign companies with main activity abroad.

- Category 3: Belgian colonial companies.

- Category 4: Belgian companies with main economic activity abroad.

- Category 5: Foreign companies with main activity in Belgium.

The first measure of stock market development only selects Belgian companies whose main economic activity is located in Belgium ('category 1'). The second measure adds the market capitalization of of category 3,4 , and 5 companies. Market capitalization is number of outstanding shares times the price at the end of December. Figure 1 plots the growth in market capitalization 
of category 1 firms computed over rolling five year periods. Prior to 1929, seventy percent of the market capitalization of the BXS consists of Belgian firms with main activity in Belgium and abroad (categories 1 and 4). ${ }^{3}$ The periods of strong growth in market capitalization are the initial development 1830-1840, the period from 1850-70, the period 1918-1929, and the last two decades 1980-2000. In the analysis below, the market capitalization is expressed in real per capita terms, where the deflation is by the consumer price index for Belgium (from Global Financial Data for 1835-2002).

The second measure of size is the total number of listed shares on the BXS. This also includes foreign companies listed on the BXS with main economic activity abroad ('category 2'). The number of shares listed closely corresponds to the number of companies listed. ${ }^{4}$ Figure 2 plots the total number of outstanding shares, whereas figure 3 displays the composition across the five categories. The number of shares listed on the BXS reaches a peak of 1597 in 1929. It drops off sharply during World War II when virtually no foreign stocks (category 2) list in Brussels. After 1945, the new listings are mostly foreign firms and the number of category 1 firms decreases steadily.

The same data set provides information on the yearly number of initial public offerings. This is a good measure of the extent to which the stock market facilitates new entrepreneurial activity. The IPO series contains information not captured by (changes in) the number of traded companies, because it measures the gross inflow of new companies, not the net flow. Figure 4 shows an active IPO market between 1890 and 1910 and between 1920 and 1935 .

To measure the international character of the BXS with the rest of the world, we use the ratio of total number of firms listed on the BXS to the number of Belgian firms with main activity in Belgium ('category 1'). This ratio is one when the only listed firms are Belgian owned firms with main activity in Belgium. A ratio of two means that there are as many firms with foreign ownership or main economic activity abroad than firms of category 1. Figure 5 shows that the international character of the BXS was increasingly pronounced between 1860 and 1910 . The ratio falls to 1 in 1945. It peaks in 1980s. In the last two decades, many international companies delisted, reducing the international character of the BXS.

One measure of the financial depth of a stock exchange is its degree of concentration. It may be difficult for new firms to obtain financing in a market with few very large firms who crowd out the smaller ones. We compute two indices of concentration: the share of the largest firm and the share of the three largest firms in category 1 in the total market capitalization of category 1 . By

\footnotetext{
${ }^{3}$ The reason why we don't use a total market capitalization index is that category 2 firms dominate the aggregate market capitalization. For foreign firms (category 2), the market capitalization is based on the global number of outstanding shares. Therefore, these companies have a very large market capitalization in our data set. This doesn't reflect the development of the BXS.

${ }^{4}$ The number of shares refers to the number of firms with shares listed, allowing for the possibility that one firm may have different classes of shares outstanding. The difference consists of companies with shares that trade in different 'tranches', such as per unit, per 10 units, per 100 units, etc.
} 
this measure, the BXS reaches its 2000 level of depth by 1850 (see figure 6). The lowest levels of concentration are found in the period 1920-1925. The largest firm only has a market share of 3 percent and the three largest firms a market capitalization that is 7 percent of the total.

\subsection{Bank-based Measures of Financial Development}

We also use two more traditional measures of financial intermediation. Deposits in commercial banks is from Mitchell for 1875-1975 and from the NBB for 1980-2002. The data from the NBB measures deposits in checking accounts and deposits at maturities below one year outstanding at credit institutions. Data for 1914-1918 are unavailable but reconstructed by assuming the same rate of growth as for the savings outstanding at the Caisse d'Epargne. Missing observations 1930 and 1934 are obtained by linear interpolation. Data for the period 1976-1979 are constructed assuming the same rate of growth as in bank note circulation.

Savings in commercial banks are from Mitchell (1980) for 1865-1975. Data on savings at the Caisse d'Epargne are available from 1865-1975, savings from the Postal Savings Office from 1870 onwards. From 1946 we also have data on private savings banks. Missing data for the postal office between 1914-1917 are constructed assuming the same growth rate as the savings in the Caisse d'Epargne. We add these three series as our measure of commercial savings. Given the dominance of the Caisse d'Epargne and the Postal Office Savings Office before World War-II, the constructed series is a good indicator of the amount of savings in the economy. Data for 1979-2002 are from the NBB. They measure deposits at maturities longer than one year, regulated savings deposits, special deposits, certificates of deposit, notes and bonds outstanding at credit institutions. Data for 1976-1978 are obtained assuming the rate of growth for commercial savings parallels the one for commercial deposits.

Savings and deposits are measured as banks' liabilities. The extent to which these funds are available in the form of long term-loans to finance commercial development determines their usefulness as a financial development indicator. This depends on maturity transformation, bank regulation, etc. for which we don't have a long data series. Since we can’t disentangle the extent to which deposits or savings are used to fund economic activity, we use one measure of bank development and sum deposits and savings. Our bank-based measure of financial development (BANK) is this sum, re-scaled in real per capita terms. This variable is available from 1875 onwards.

Finally, we use bank note circulation data from Mitchell (1980) for 1851-1975 and from the National Bank of Belgium (NBB) for 1976-1998 as a second and coarser measure of bank development. Starting in 1999, the measure is Belgium's contribution to the European monetary union's total currency in circulation. We only use this measure to have some proxy for bank development in the beginning of the sample (pre-1873). 


\subsection{Economic Activity}

Our measure of growth is the annual percentage increase, measured as a log difference, in real per capita gross domestic product (GDP). GDP data are from Maddison (1995) for the period 1870-1994. These data are measured per capita in constant dollars (basis 1990). There is also a data point for 1820 and 1850. For the period 1995-2002 we use real GDP per capita growth rates (at constant prices) from the World Economic Outlook. We interpolate between the 1820, 1850 and 1870 observation using annual industrial production data from Vandermotten (1980) for 1846-1870 and annual data on coal mine productivity from Caulier-Mathy (1986) for 1830-1846. To convert them into Belgian francs we use the exchange rate in 1990 (Global Financial Data). Figure 7 shows volatile growth rates in the 1918-1940 period.

Before moving to the empirical results in section 6 , we first describe the historical context and highlight the institutional factors that are important for the analysis.

\section{Historical Context}

Anticipating the empirical results in section 6, we find that the nature of the relationship between stock exchange development and economic growth changes over time. While stock market capitalization drives GDP growth over the entire sample period, we find no strong relationship in the period prior 1873. From 1873 on this seems on the reverse, but from 1980 on the pattern changes once again. These findings are supported by a systematic analysis of the changing characteristics of the institutional environment surrounding the stock market.

1830-1873 A dual set of legal restrictions affected the stock exchange. On the one hand, the law imposed many restrictions on starting up a joint-stock company. This law originated in the state-controlled Napoleonic system that only permitted joint-stock companies with government approval. Under the law, permission was refused when there were doubts about the commercial nature of the activity or when a similar kind of enterprize already existed. In addition, the issuance of stocks and bonds was restricted, effectively restricting companies' access to capital markets and their composition of equity and bonds funding. On the other hand there were direct restrictions on the stock exchange. For a joint-stock company to trade on the exchange, a special admission rule was in place. Railway companies, forming the largest industry at the time, were not allowed to have their stocks quoted as long as the railways were under construction. As a result, railway companies to be quoted at the London and Paris stock exchange, but not in Brussels. The biggest private railway company, Grand Luxembourg, was founded in 1846, but it was not admitted until 1858 under this rule. In the intervening years, it was unable to collect the necessary funds. As such, it was hardly surprising that the Brussels stock market witnessed the emergence of a second, 
more informal stock exchange, the Lloyd Bruxellois. Until the liberalization of the stock market in 1867, the trading volume in stocks at the Lloyd Bruxellois was higher than at the official BXS.

These restrictions did not halt economic growth. Belgium was one of the first countries on the continent to industrialize. It ranked second in industrial output per capita in 1860, only preceded by England. From 1834-1838 onwards, sectors such as coal mining, steel, textiles and railways rose in importance.

Two universal banks, the Société Générale (SG) and the Banque de Belgique (BB), took the lead in financing the industrialization process. They set up subsidiaries who participated directly in new ventures, and they provided loans to investors in joint-stock companies. During the period 1834-1838, the onset of Belgian industrial revolution, 151 joint-stock companies sprung up. So, the restrictive legislative character of the stock exchange implied that economic development was mainly financed by intermediaries different from the BXS. However, in their role of venture capitalists, the SG and the BB fostered the initial development of the BXS because they brought many firms to the stock exchange. ${ }^{5}$ As true venture capitalists they actively sought new firms (ex ante screening), underwrote their stock issues and placed their officers on the board of directors (monitoring). They fulfilled most of the growth promoting functions described in section 2 .

In addition, the mixed banks promoted stock market participation by providing loans to investors who had otherwise insufficient capital to participate in the stock market. However, when these investors could not fulfill their obligations during the first industrial and financial crisis of 1838-1839, the mixed banks took over their shares. As a result, they held a majority stake in many newly founded joint stock companies. This situation persisted because the BXS lacked the liquidity to absorb large quantities of funds. One of the factors that limited broad stock market participation and financial deepening of the BXS was a lack of divisibility of shares. The price of one share was often so high that trade was infrequent, and hence liquidity adversely affected.

1873-1914 After the 1873 law on joint-stock companies was passed, the Brussels stock exchange experienced its fastest development. This law abolished government approval to start a limited liability company, and was complementary to the 1867 reform on stock exchanges in which the government gave up its right to ban companies from trading on the exchange. From 1873 onwards

\footnotetext{
${ }^{5}$ The universal banks were more than just financial intermediaries who extended bank loans; they acted as venture capitalists by directly participating in the equity of the new firms. They used the deposits of the bank to build up powerful positions in industry and mining. The Société Générale invested through two subsidiaries, the Société de Commerce and the Société Nationale pour Entreprises Industrielles et Commerciales, and one investment company the Société des Capitalistes Réunis dans un But de Mutualité Industrielle. The Banque de Belgique acted with the help of the investment company Actions Réunies. For instance, the SG built up a private railway network that was at least as strong as the state railways. Its interests represented nearly the complete capital of the railroad companies. When in 1852 several railway companies were founded, the SG took a leading interest. In particular, the Chemins de Fer de Charleroi à Louvain, the Chemin de Fer de Dendre et Waes et de Bruxelles vers Gand. Likewise, the BB acquired a railway network of comparable magnitude, consisting of the Bassins Houillers du Hainaut and later the Société Générale d'exploitation. For a detailed analysis of the Belgian mixed banks and their networks, see Cuyvers and Meeusen (1976) and Cuyvers and Meeusen (1985).
} 
a manifold of joint stock companies were formed and allowed on the stock exchange. Many, often small, companies now obtained their initial capital on the stock exchange and their shares started trading right away. In addition, many existing companies were transformed into joint stock companies and their stocks floated on the stock exchange. Between 1873 and 1914, the total number of listed shares increased from 174 to 1197 (figure 2). The decreasing concentration on the BXS is another sign of its financial deepening (figure 6). This was a period of financial stability (figure 7). Unit prices of stocks were somewhat lower and personal income higher so that liquidity improved and participation rates went up.

The abundance of capital enabled investments abroad. The relative importance of Belgian firms with main activity abroad (category 4) increased dramatically (figure 3). Reversely, Belgium attracted a lot of capital from abroad, in part due to the favorable tax treatment. ${ }^{6}$ Many of these foreign companies used their stocks and bonds that were trading on the exchange as a means of payments for Belgian exports. Given this link between cross-border financial investment (figure 5) and a growing globalization of trade, it is unsurprising to us that we find the strongest link between stock market development and economic growth in this era. The universal banks also profit from the new situation, because more capital became available through the stock exchange. This situation would last until 1914.

1914-1935 In the period 1914-1935, Belgium witnessed the first World War with devastating economic consequences on the European continent, the long lasting crisis of the thirties, and a reversal of the laws of $1867-1873$.

A first important factor was the massive concentration in the banking sector. Due to the War and the German occupation, the capital basis of most companies, including banks, had weakened. Stimulated by the law of July 23 1927, banks recapitalized through a process of concentration. ${ }^{7}$ Second, a system of multiple votes per share allowed the universla banks to gain control over a company with a stake as small as three percent of the equity. This freed up a lot of capital that the mixed banks invested domestically and in Congo, Belgian's colony. The banks issued capital for a wide variety of colonial ventures. Investment in Congo was considered a safe alternative by investors who were scarred by the tremendous losses on European investments. ${ }^{8}$ The economic exploitation of Congo provided Belgium with an inflow of raw materials and colonial products that positively impacted economic growth. The Belgian economy flourished in the years before the great depression.

\footnotetext{
${ }^{6}$ Belgium had a system of practically no taxation on company profits or dividends, in contrast to many other countries.

${ }^{7}$ For example, the Société Générale merged with the Banque d'Outremer in 1928, making it one of the biggest European banks of the time.

${ }^{8}$ Financial losses from the First World War were enormous. For example, investors lost all their investments in Russia. Furthermore, the inflation due to the War meant an abrupt break with a century old history of stable prices prior to 1914.
} 
1935-2002 The 1934-1935 reforms of the stock exchange and the financial system tightened government control over the stock exchange, but not to the extent that this meant a return to the pre-1867 system. The banking system was reformed and the universal banks were split into a deposit banks and 'holding companies', industrial conglomerates. The laws attempted to revive the economy, but only had a modest impact.

During the Second Word War the stock exchange remained open but was reserved for Belgian stocks only. With the exception of the Korean War, the economy went through a rather difficult period until 1958. After the independence of Congo in 1960 and especially after the nationalization wave in 1967, nearly all colonial companies were transformed into holding companies. Many of them disappeared from the stock exchange. This was the beginning of a trend of growing internationalization of the BXS and decreasing importance of Belgian firms (see figure 5 after 1980).

During the two oil crises in 1974 and 1979, traditional industries (coal mining, steel, shipbuilding, textiles, glass) increasingly met with severe difficulties. State subsidies were ultimately unable to keep them alive, and many companies disappeared from the stock market. ${ }^{9}$ The economic crisis of the seventies culminated in the fast increase of Belgian public debt and eventual devaluation of the Belgian Franc in 1982. With the establishment of the European Economic Community in 1958, Brussels became the headquarters of Europe. Taken together with the growing importance of the Antwerp harbor, this compensated for the losses in industrial and mining sectors.

The law Cooreman-De Clercq (1982) succeeded in reviving the attractiveness of the stock market. As in most other developed economies, the BXS witnessed an increase in stock market participation and a fast rate of growth of market capitalization in the eighties and nineties (figure 1). However, this would not reverse the continual decline of Belgian owned companies traded on the BXS (figure 3). Eventually, the Brussels stock exchange itself became involved in this process of internationalization. Two centuries after its creation, the Brussels stock market ceased to exist as an autonomous institution in 2001. Together with the Dutch and French stock exchange, it forms a new exchange, Euronext.

\section{Results}

In this section, we start with a brief description of the Granger-causality and cointegration procedures before reporting the main empirical results.

\subsection{Econometric Analysis}

We are interested in the causal relationship between financial development and economic growth. Prior to 1990, the most widely used concept of causality was Granger's notion of causality for tem-

\footnotetext{
${ }^{9}$ Even the Société Générale was taken over by the French-based Suez holding company.
} 
poral systems. Financial development $(\mathrm{F})$ does not Granger causes economic growth $(\mathrm{Y})$ when inclusion of the history of $\mathrm{F}$ cannot help reduce the prediction error of next period's $\mathrm{Y}$. Granger causality implies predictability and exogeneity. If the time-series under investigation are not stationary, the first differences $(\Delta F$ and $\Delta Y)$ are calculated and Granger causality tests proceed as before. This method is inaccurate in that it eliminates the long-term relationship between the variables under consideration (Johansen and Juselius (1990)). With these caveats in mind, we perform a Granger causality test in section 6 .

Cointegration techniques avoid these difficulties as they primarily look for stable long-run equilibria between variables. The cointegration analysis starts from a system of error correction equations, one for each variable under consideration. All variables of interest are endogenous. The data will determine which ones are exogenous, and hence speak to the direction of causality. Appendix A describes the cointegration procedure in detail. The resulting system we estimate is

$$
\begin{aligned}
\Delta F_{t} & =\Gamma_{F F} \Delta F_{t-1}+\Gamma_{F Y} \Delta Y_{t-1}+\alpha_{F}\left(\beta_{F} F_{t-1}+\beta_{Y} Y_{t-1}\right)+\mu_{F}+\varepsilon_{F t} \\
\Delta Y_{t} & =\Gamma_{Y F} \Delta F_{t-1}+\Gamma_{Y Y} \Delta Y_{t-1}+\alpha_{Y}\left(\beta_{F} F_{t-1}+\beta_{Y} Y_{t-1}\right)+\mu_{Y}+\varepsilon_{Y t}
\end{aligned}
$$

where $\alpha_{F}$ and $\alpha_{Y}$ measure the speed of convergence towards the long-run equilibrium and $\beta_{F}$ and $\beta_{Y}$ are the cointegration coefficients. In the bivariate system of financial development $(\mathrm{F})$ and economic activity $(\mathrm{Y})$ with a single cointegration vector, financial development causes economic growth when $Y$ reacts to a deviation from the equilibrium relationship $\left(\beta_{F} F_{t-1}+\beta_{Y} Y_{t-1}\right)$ and when $F$ does not. This is the case when the null hypothesis $H_{0}: \alpha_{F}=0$ and $\alpha_{Y} \neq 0$ cannot be rejected. We say that financial development is weakly exogenous because $\mathrm{F}$ does not react to disequilibrium errors between $\mathrm{F}$ and $\mathrm{Y}$. However, F may still react to lagged changes in $\mathrm{Y}$ (non-zero $\Gamma_{F F}$ and $\left.\Gamma_{F Y}\right)$. Strong exogeneity disallows also the latter reaction. Growth causes finance in the opposite case. When we estimate the above VECM we impose $\beta_{Y}=1$. This amounts to rescaling the coefficient in the cointegration relationship, $\beta=\frac{\beta_{F}}{\beta_{Y}}$, and the adjustment speed $\frac{\alpha_{i}}{\beta_{Y}}, i=F, Y$.

\subsection{Granger Causality}

Table 1 reports Granger Causality tests for a system of economic growth (Y), measured by real per capita gross domestic product, and financial development (F). Financial development is measured by stock market capitalization (MK) and savings plus deposits (BANK). All variables are expressed in real Belgian francs and first differences are taken. The resulting variables are stationary according to an Augmented Dickey Fuller test for unit roots (results not reported). Table 1 reports the test results for the null hypothesis of no Granger causality. We choose a lag length of five years as the horizon over which the variables can help predict each other. We investigate Granger causality for the entire sample and for various sub-samples whose breakpoints were motivated by 
legislative changes in the financial sector in section 5 .

We find that the growth in stock market capitalization Granger causes GDP growth in the pre-1914 and the entire sample (row 1). The null hypothesis of no Granger causality from finance development to economic growth is rejected at the 1 percent level. Measured by growth in market capitalization, the 1873-1935 period the most buoyant (see figure 1). The econometric evidence says that this market capitalization preceded GDP growth in that period (fourth column). In the last part of the sample (fifth column), GDP growth Granger causes stock market development. Especially after the Second World War, the internationalization of the Brussels Stock Exchange changed the nature of the finance-growth nexus. The share of the multinational foreign-based companies in the market capitalization of the BXS increased strongly. Given this trend, we are unsurprised to find a weak link between the market capitalization of Belgian-owned firms with main production facilities in Belgium (category 1) and economic growth.

As for bank development, deposits and savings growth strongly Granger causes economic growth post-1914 and in the entire sample starting in 1875 (row 2). Losses incurred by bond defaults after the First World War and concentration in the bank sector may explain the growth promoting role of banks post-1914. The measure of bank development that uses the outstanding money supply is unrelated to economic growth in Belgium (not reported).

In rows 3, we estimate Granger causality for a trivariate system with the stock market development and the bank development variable combined. The effects of the stock market capitalization on growth are robust to the inclusion of bank development variables. Both stock market capitalization and deposits and savings growth predict GDP growth. For the 1875-1914 and 1875-1935 periods the data suggest that stock market development leads economic growth, but banking development does not. in the latter period there is some evidence that bank development precedes stock market development, but only at the $10 \%$ level. In the post-1935 period, banking growth Granger causes GDP growth which Granger causes stock market capitalization growth.

The analysis conveys that stock market development and bank development both, and independently, predict economic growth. The former is concentrated in the pre-1914 period; the latter in the post-1914 period.

\subsection{Cointegration Analysis}

Stock Market Capitalization and GDP The Johansen Cointegration tests identify the number of cointegration relations. The max eigenvalue and trace test both indicate one cointegration relationship at the 1 percent level. ${ }^{10}$ The fact that GDP and stock market capitalization (both category 1 firms and the sum of category 1, 3, 4, and 5 firms) have a long-run equilibrium relationship has a natural interpretation. The stocks are a claim to their profits, which constitute

\footnotetext{
${ }^{10}$ This assumes a linear trend in the data, an intercept and no trend in the cointegration relationship.
} 
the added value the country produces, i.e. GDP. There cannot be a permanent deviation between the two variables. Ultimately, the stock market value of these stocks must reflect their fundamental value: the present discounted value of GDP.

In a second step we estimate the bi-variate error correction model (VECM) for real per capita GDP and real per capita stock market capitalization. The left panel of Table 2 displays the results using the market capitalization of firms of category 1 only, and the right panel uses all Belgian firms and foreign firms with economic activity in Belgium (categories 1, 3, 4, and 5). The speed of adjustment coefficient $\alpha$ is significant in the GDP growth equation, but not in the market capitalization equation. This indicates that GDP responds to deviations from the long-run relationship between economic growth and stock market development. However, market capitalization does not respond to such deviations. The null hypothesis $H_{0}: \alpha_{F}=0$ and $\alpha_{Y} \neq 0$ cannot be rejected. We conclude that GDP is weakly exogenous in the long sample. Furthermore, market capitalization does not react to short-run changes in GDP: The $\Gamma_{F Y}$ coefficient is not statistically significant (whereas $\Gamma_{Y F}$ is), and hence we can conclude strong exogeneity of stock market capitalization. Put differently, after a deviation, the adjustment towards the long-term stock market development - economic growth relationship is accomplished by an increase in the growth rate in GDP. The long-run relationship between stock market development and GDP and short-run changes in stock market development together explain a large part of the changes in GDP: The $R^{2}$ of the first error-correction equation is $36 \%$.

Both market capitalization measures employed here measure the quantity of shares outstanding times the market price of shares deflated by the consumer price index. Rousseau and Wachtel (2000) argue that this measure may increase because a run-up in stock prices (while the general price level is constant) which does not reflect a deepening of the financial system. They advocate re-scaling market capitalization by stock prices instead. As a robustness check, we redid the analysis in Table 2 with a measure of market capitalization rescaled by the all shares price index. The results were qualitatively unchanged: Stock market development causes economic growth $\left(\alpha_{Y}\right.$ is strongly significant, whereas $\alpha_{F}$ is basically zero). Also, $\Gamma_{Y F}$ is significant at the $10 \%$ level, confirming that stock market development is strongly exogenous. We next turn to an analysis of the different sub-periods. Then, we investigate other measures of stock market deepening, such as the number of listed firms and the number of initial public offerings that are not subject to the above criticism.

Subperiods The picture looks more subtle when we look at the various sub-samples, where the breakpoints were motivated in section 5 . In the pre-1914 period, we find evidence that economic growth drives stock market development. The first pair of columns of table 3 shows that GDP is weakly exogenous in the pre-1914 period. Stock market capitalization reacts to a deviation from its equilibrium relationship with GDP, the reverse is not true. In the short run, finance influences 
growth: The one year lagged change in stock market development enters significantly. Hence, GDP is not strongly exogenous. The third pair of columns show that the weak exogeneity of GDP is due to the initial period 1832-1873. In this period, stock market capitalization reacts significantly to changes in the cointegration relationship, as well as to short run changes in GDP. We recall from section 5 that 1873 is when the laws governing the stock market became more liberal. In 1935, the legislative pendulum again swung the other way. The last panel confirms that the results for the 1873-1935 period are indeed different than before 1873. GDP now reacts to stock market development, both in the long-run and the short run. Stock market development still reacts to GDP in the long-run, but not in the short run. This is the period in which we explain the most variation in GDP growth interms of $R^{2}$. In the period 1914-2002 (second panel), the results are as in the entire sample: The market capitalization is strongly exogenous. Stock market development is a driving force of economic development in this period. In conclusion, the effect of stock market development to economic growth is the strongest after 1873. To gauge the economic impact, we compute an impulse-response for the period 1873-2002. A 100 BEF increase in market capitalization leads to a 5.5 BEF increase in real GDP per capita after 1 year, a 61.5 BEF cumulative increase after 10 years, and even a 160 BEF increase after 20 years. Or put differently, a one standard deviation increase in market capitalization (95,000 BEF or a doubling of the 1873 level), leads to an increase of 16,200 BEF in GDP after 10 years, a large magnitude given that real GDP per capita was 85,000 BEF in 1873 . The results in Table 3 are unchanged when we include the market capitalization of firms in categories 3,4 , and 5 .

\section{Other Stock Market Development Indicators}

We study the long-run relationship between GDP and four other measures of stock market development. They are the number of listed shares of category 1 firms, the cumulative number of IPOs, the international character of the BXS and the degree of concentration (market share of largest firm). We focus on the longest available sample for each variable. Table 4 reports the estimates for the cointegration and the speed of adjustment coefficients.

We find a cointegration relationship between all four variables and GDP at the five percent level or better. The first column indicates that the direction of causality runs from the number of listed shares to GDP. Not only the total market capitalization, but also the number of Belgian firms listed on the BXS affects economic growth in Belgium. The deepening of the BXS, not the mere increase in the market capitalization of a few large firms, is related to economic growth. The (cumulative) number of initial public offerings also significantly leads economic growth. Since this is a measure of entrepreneurial activity and innovation, this is econometric evidence that the innovation-facilitating role of the stock market is robustly associated with economic development. Likewise, the variable measuring the international character of the BXS is weakly exogenous with 
respect to economic growth. An increase in the international character of the BXS leads to higher GDP growth in the long-run. Finally, there is a bi-directional relationship between concentration and GDP. A positive shock to concentration leads to a decrease in GDP. In sum, the evidence from other stock market development measures provides additional support that the deepening of the stock exchange positively affected economic growth in Belgium.

Measures of Bank Development Similarly to the Granger causality analysis, we estimate a trivariate VECM with GDP, stock market capitalization, and our measure of bank development, which aggregates deposits and savings. The bank development measure starts in 1875, restricting the analysis to the period 1875-2002. We assume a linear trend in the data and a constant but no trend in the cointegration relationship. We find strong evidence for 1 cointegrating relationship between GDP, MK, and BANK. In particular, we find no evidence for a separate long-run equilibrium relation between bank development and stock market development (BANK and MK).

Table 5 reports the VECM estimates of the cointegration coefficients, the speeds of adjustment and the first lagged differenced term. The results show that stock market capitalization is strongly exogenous. Both GDP and bank development adjust to deviations from the long-run relationship. In the short-run, GDP reacts to both stock market and bank development. In sum, the importance of stock market development for GDP growth is robust to inclusion of a measure of bank development. In fact the evidence suggest that stock market development was a more significant driver of economic growth. Since the sample only starts in 1875 , we are confined to the period after the liberalization of the stock market with the laws of 1867 and 1873.

The historical evidence suggests that pre-1873, the universal banks (especially the the Société Générale and the Banque de Belgique) played a very important role in fostering economic growth and in fostering the initial development of the BXS. One albeit coarse way of quantifying this role is to look at bank note circulation (the only other measure of financial development available starting 1853). Bank note circulation, market capitalization, and GDP are cointegrated in the earlier period 1853-1914. In this early period, stock market capitalization reacts to changes in the cointegrating relationship, whereas the other two variables do not. This is some evidence of banking causing stock market development in the early period.

\section{Conclusion}

Large production factors require the permanent commitment of an unprecedented quantity of capital. The stock market facilitates raising this capital. This paper has presented both descriptive and quantitative evidence that financial development and in particular the availability of stock market based financing for firms was an important determinant of economic growth of Belgium. The strongest effects are found in the post-1873 period. The removal of the restrictions on the 
formation of limited liability companies, the removal of the restrictions on trade in the shares of these firms on the stock exchange, and the improved liquidity of trade around 1870 provided the final impetus for an accelerated development of the Brussels stock exchange. In a cointegration analysis, we find the strongest evidence for the growth-promoting role of the stock market. Also, we find that stock market development was a better forecaster of economic growth than bank-based development. Based on descriptive historical evidence, we have argued that universal banks played an important role for economic growth pre-1873, not only by directly financing entrepreneurial activity, but also by fostering the initial development of the stock exchange.

Gurley and Shaw (1955) complain about the

"inadvertent undervaluation by economists of the role that finance plays in determining the pace and pattern of growth."

We have presented historical and econometric evidence that the stock market played an important role in the economic development of Belgium. In additional results, not reported in the paper, we controlled for other growth-inducing variables put forward in the literature, and found the results to be robust. Nevertheless, caution remains: mono-causal explanations underestimate conflicting tendencies and the complexity of history. In recognition, we carefully examined the institutional changes and found that they lined up with the econometric changes in the relationship between the stock market development and economic growth. 


\section{Figures and Tables}

Figure 1: Long-Term Evolution of Market Capitalization.

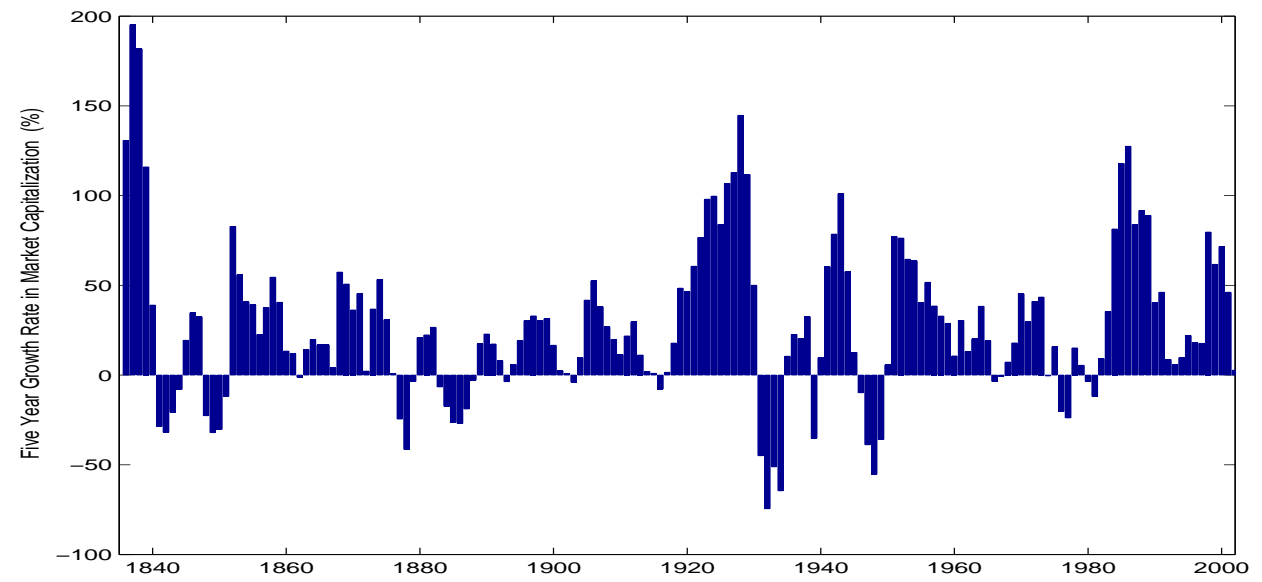

Five year growth rate in market capitalization of category 1 firms (1835-2002). Category 1 is Belgian firms with main activity in Belgium. Source: SCOB. 
Figure 2: Total Number of Outstanding Shares on the BXS 1832-2002.

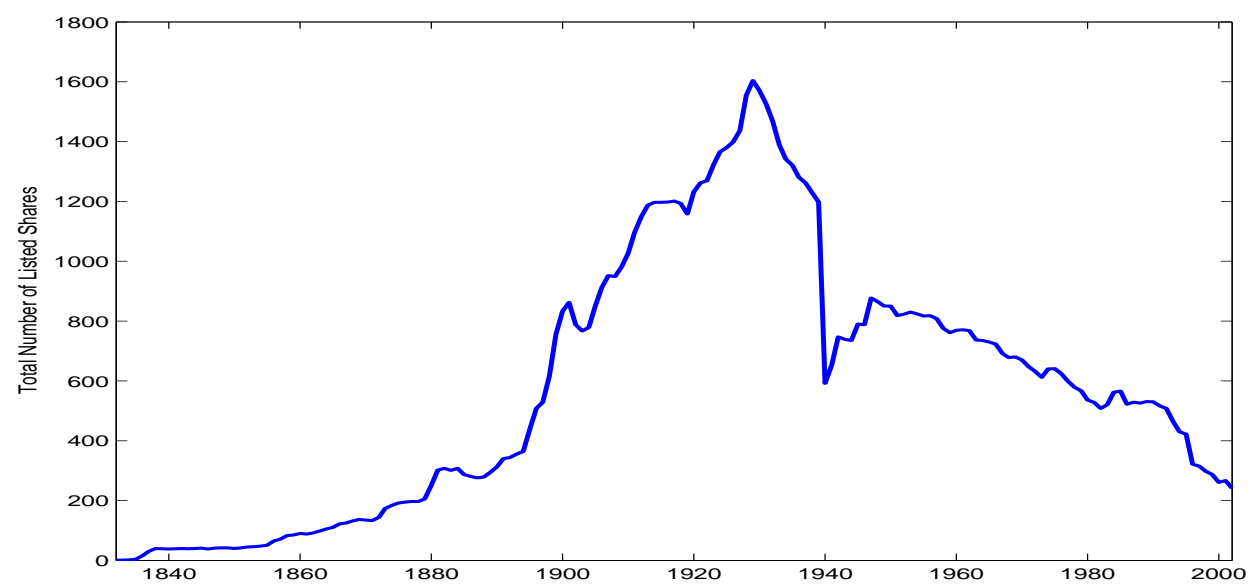

Source: SCOB. 
Figure 3: Composition of Outstanding Shares on the BXS (1832-2002).

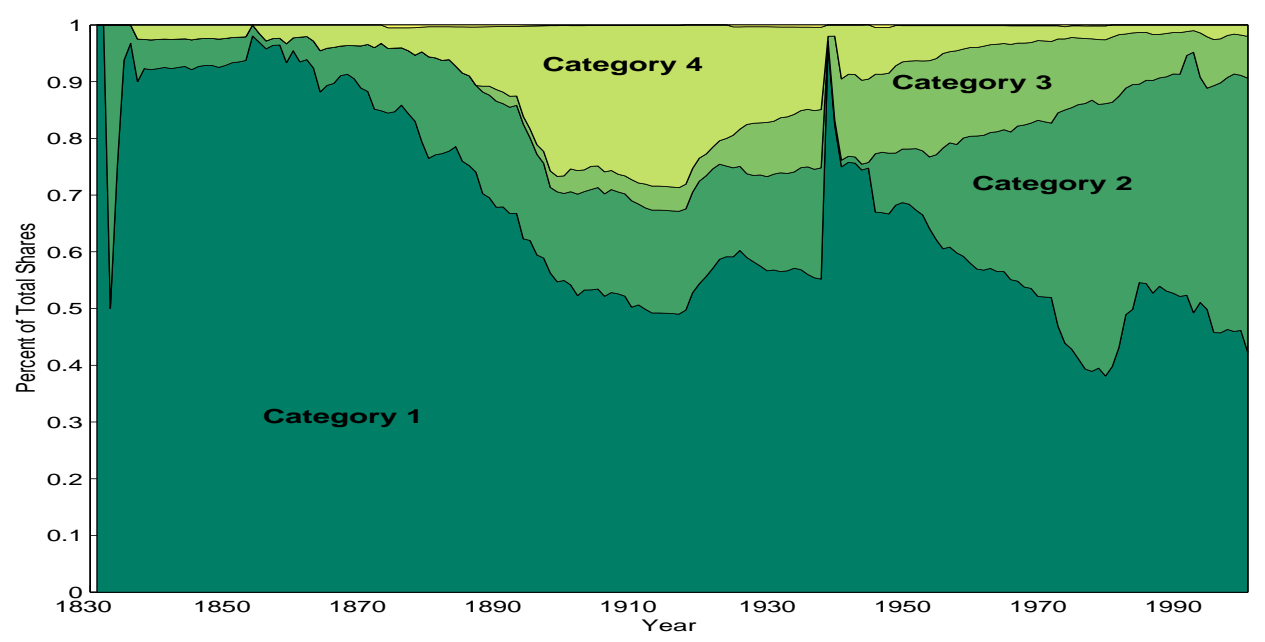

Category 1 is Belgian firms with main activity in Belgium, category 2 is foreign firms with main activity abroad, category three is Belgian colonial firms, category 4 is Belgian firms with main activity abroad and category 5 is foreign firms with main activity in Belgium. The latter category is very small and hardly visible in the plot. Source: SCOB. 
Figure 4: Number of IPO's on the Belgian Stock Exchange 1830-2000.

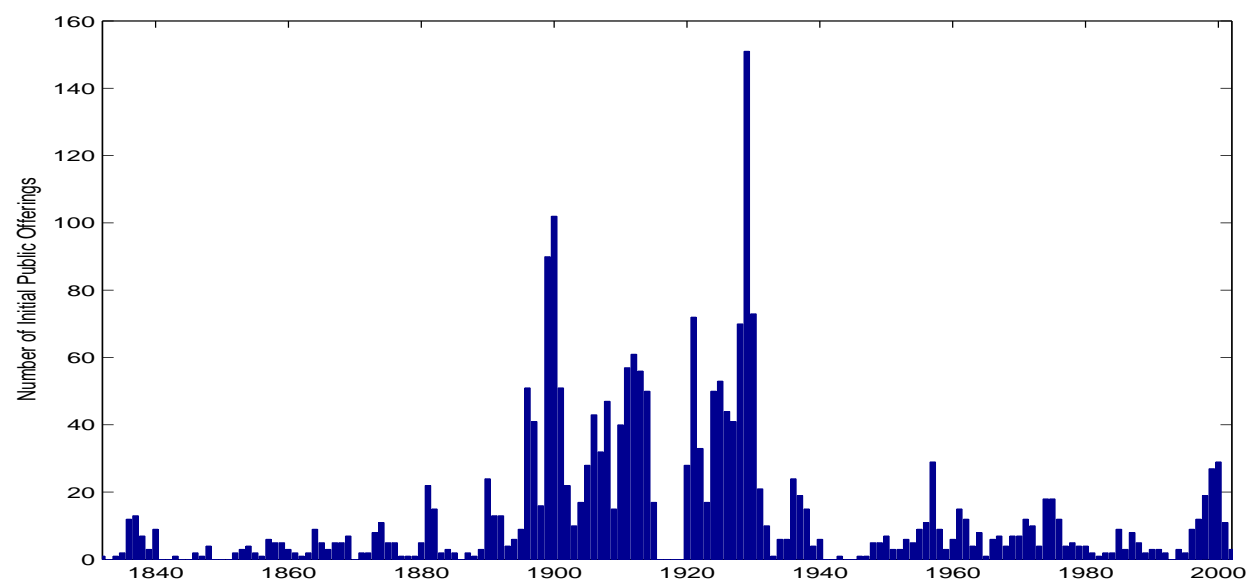

New stock listings, per year. Source: SCOB. 
Figure 5: International Character BXS 1832-2002.

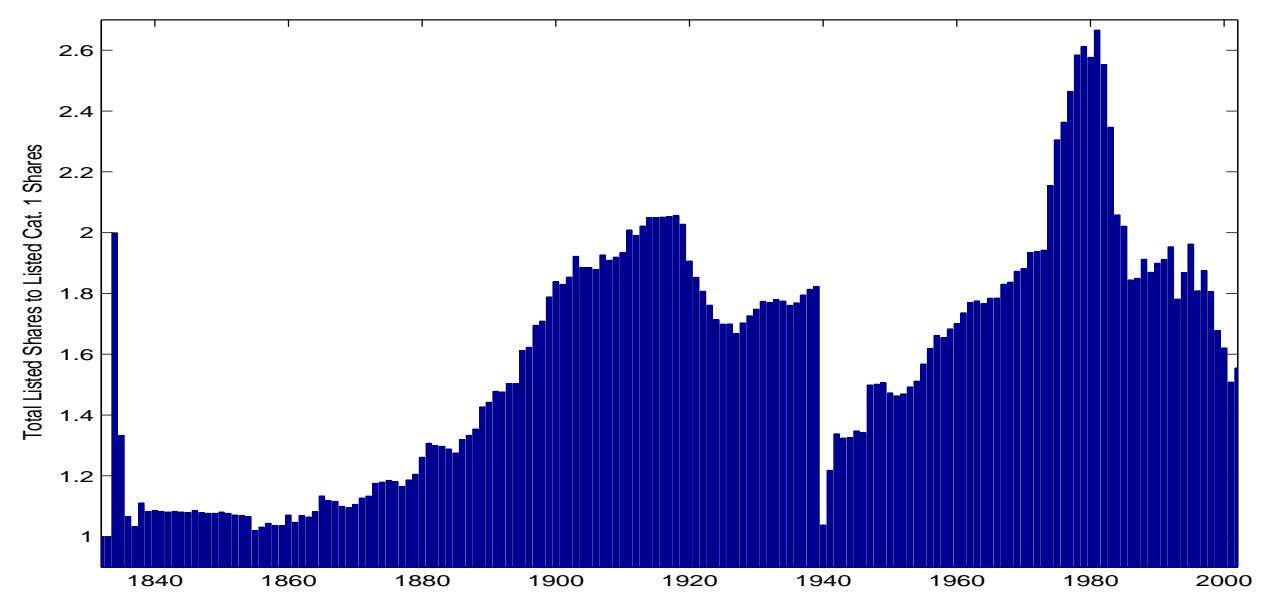

Number of firms of categories 1-5 divided by the number of firms of category 1 . Category 1 is Belgian firms with main activity in Belgium, category 2 is foreign firms with main activity abroad, category three is Belgian colonial firms, category 4 is Belgian firms with main activity abroad and category 5 is foreign firms with main activity in Belgium. Source: SCOB. 
Figure 6: Concentration on BXS 1832-2002.

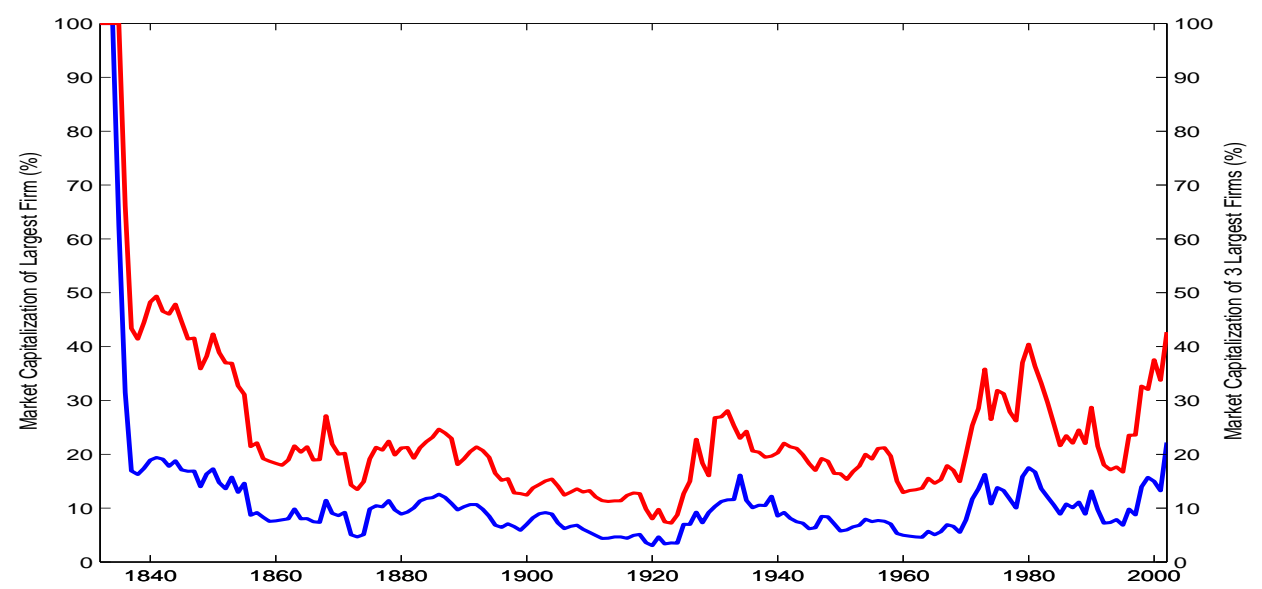

The top line displays the share of the largest 3 firms in category 1 in the total market capitalization of category 1 . The bottom line displays the share of the largest firm in category 1. Source: SCOB. 
Figure 7: Economic Growth in Belgium 1832-2002.

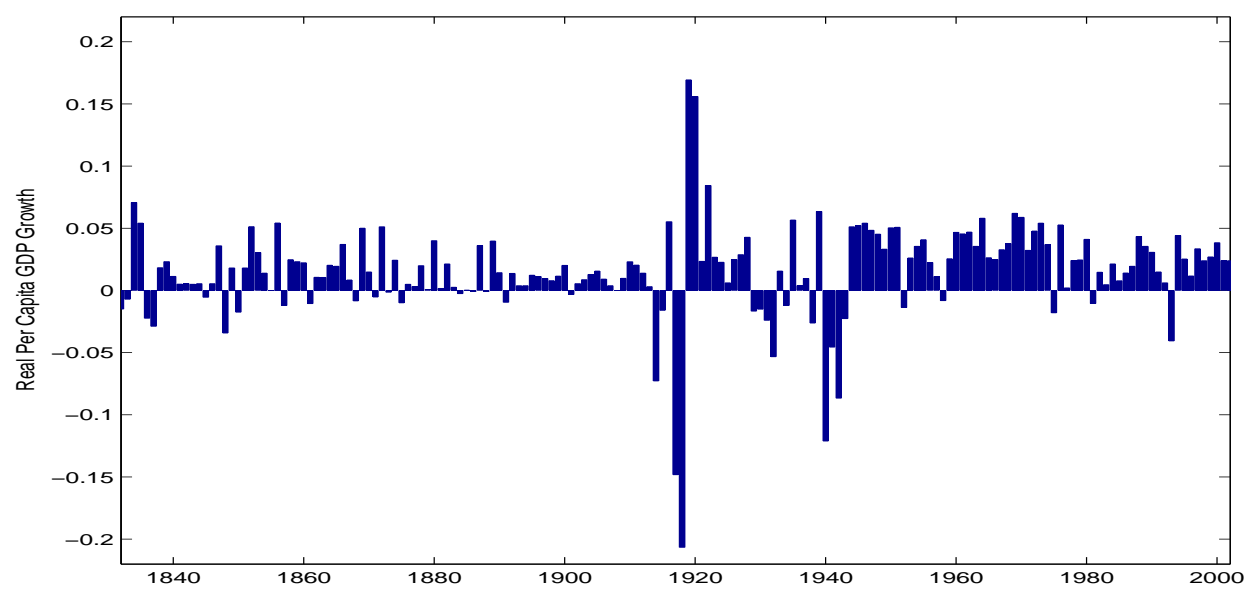

Log change in a gross domestic product per capita deflated by the consumer price index. Source: Maddison (1995) 
Table 1: Granger Causality Analysis

\begin{tabular}{|l|c|cccc|}
\hline System & $1832-2002$ & $1832-1914$ & $1914-2002$ & $1873-1935$ & $1935-2002$ \\
\hline 1. GDP-MK & $M K \rightarrow Y^{* * *}$ & $M K \rightarrow Y^{* * *}$ & No GC & $M K \rightarrow Y^{* *}$ & $Y \rightarrow M K^{*}$ \\
2. GDP-BANK & $B A N K \rightarrow Y^{* * *}$ & No GC & $B A N K \rightarrow Y^{* * *}$ & no GC & $B A N K \rightarrow Y^{* * *}$ \\
\hline 3. GDP-MK-BANK & $M K \rightarrow Y^{* * *}$ & $M K \rightarrow Y^{* * *}$ & $M K \rightarrow Y^{* * *}$ & $M K \rightarrow Y^{* * *}$ & $Y \rightarrow M K^{*}$ \\
& $B A N K \rightarrow Y^{* * *}$ & & & $B A N K \rightarrow M K^{*}$ & $B A N K \rightarrow Y^{* * *}$ \\
\hline
\end{tabular}

MK is stock market capitalization of stocks in category 1. DEP is deposits in credit institutions with maturity less than one year. SAV is savings in credit institutions. GDP is gross domestic product. We deflate variables by the consumer price index and divide by the population. We then take log differences of all variables. The lag length in the Granger causality test is 5 years. The bank development measure is only available after 1875 and not for the period 1914-1918. The notation *** denotes rejection of the null hypothesis of no Granger causality at the 1 percent level, ${ }^{* *}$ at the 5 percent level and ${ }^{*}$ at the 10 percent level. 
Table 2: VECM Estimation for GDP and Stock Market Capitalization.

\begin{tabular}{|l|cc|cc|}
\hline Cointegrating Eq & \multicolumn{2}{|c|}{ Category 1 MK } & \multicolumn{2}{c|}{ Category 1,3,4,5 MK } \\
\hline$\beta$ & \multicolumn{2}{|c|}{.044} & \multicolumn{2}{c|}{-.195} \\
& \multicolumn{2}{|c|}{$(.280)$} & \multicolumn{2}{c|}{$(.222)$} \\
\hline VECM & $\Delta Y_{t}$ & $\Delta F_{t}$ & $\Delta Y_{t}$ & $\Delta F_{t}$ \\
\hline$\alpha_{i}$ & $.021^{* * *}$ & .022 & $.024^{* * *}$ & .028 \\
& $(.003)$ & $(.015)$ & $(.004)$ & $(.019)$ \\
$\Gamma_{i Y}$ & .070 & .273 & .068 & .189 \\
& $(.084)$ & $(.360)$ & $(.084)$ & $(.412)$ \\
$\Gamma_{i F}$ & $.055^{* *}$ & -.041 & $.0553^{* * *}$ & .047 \\
& $(.020)$ & $(.082)$ & $(.016)$ & $(.081)$ \\
\hline Adj. R-squared & 0.361 & 0.024 & 0.374 & 0.036 \\
\hline Observations & \multicolumn{2}{|c|}{154} & \multicolumn{2}{c|}{154} \\
\hline
\end{tabular}

The variables are real per capita stock market capitalization of category 1 firms (left panel) and category $1,3,4$ and 5 firms (right panel) and real per capita GDP. The sample is the full sample from 1832-2002 and contains 154 observations after adjusting the endpoints. We assume a linear trend in the data, an intercept and no trend in the cointegration relationship. The VECM has 1 lagged differenced variable term in the estimation. Standard errors for the coefficient estimates are in parentheses. *** denotes significance at the 1 percent level, ${ }^{* *}$ at the 5 percent level and ${ }^{*}$ at the 10 percent level. 
Table 3: VECM Estimation for the Bivariate Model: Sub-periods.

\begin{tabular}{|c|c|c|c|c|c|c|c|c|}
\hline Cointegrating Eq & \multirow{2}{*}{\multicolumn{2}{|c|}{$\begin{array}{c}1832-1914 \\
-0.981^{* * *} \\
(.075)\end{array}$}} & \multirow{2}{*}{\multicolumn{2}{|c|}{$\begin{array}{c}1914-2002 \\
.214 \\
(.518)\end{array}$}} & \multirow{2}{*}{\multicolumn{2}{|c|}{$\begin{array}{c}1832-1873 \\
-.936^{* * *} \\
(.103)\end{array}$}} & \multirow{2}{*}{\multicolumn{2}{|c|}{$\begin{array}{c}1873-1935 \\
-1.038^{* * *} \\
(.131)\end{array}$}} \\
\hline$\beta$ & & & & & & & & \\
\hline VECM & $\Delta Y_{t}$ & $\Delta F_{t}$ & $\Delta Y_{t}$ & $\overline{\Delta F_{t}}$ & $\Delta Y_{t}$ & $\Delta F_{t}$ & $\Delta Y_{t}$ & $\Delta F_{t}$ \\
\hline$\alpha_{i}$ & $\begin{array}{l}0.015 \\
(.026)\end{array}$ & $\begin{array}{l}.299^{* * *} \\
(.076)\end{array}$ & $\begin{array}{c}0.018^{* * *} \\
(.006)\end{array}$ & $\begin{array}{c}.023 \\
(.024)\end{array}$ & $\begin{array}{r}-0.015 \\
(.070)\end{array}$ & $\begin{array}{l}.661^{* * *} \\
(164)\end{array}$ & $\begin{array}{c}0.076^{* * *} \\
(.022)\end{array}$ & $\begin{array}{l}.445^{* * *} \\
(101)\end{array}$ \\
\hline$\Gamma_{i Y}$ & $\begin{array}{l}-0.156 \\
(.142)\end{array}$ & $\begin{array}{c}-.302 \\
(0.410)\end{array}$ & $\begin{array}{c}0.053 \\
(0.121)\end{array}$ & $\begin{array}{c}.328 \\
(.529)\end{array}$ & $\begin{array}{c}-0.119 \\
(.160)\end{array}$ & $\begin{array}{l}-.746^{* *} \\
(0.374)\end{array}$ & $\begin{array}{c}-0.055 \\
(.115)\end{array}$ & $\begin{array}{l}-.314 \\
(.516)\end{array}$ \\
\hline$\Gamma_{i F}$ & $\begin{array}{c}0.120^{* *} \\
(.040)\end{array}$ & $\begin{array}{l}.366^{* * *} \\
(.114)\end{array}$ & $\begin{array}{l}.053^{* *} \\
(.027)\end{array}$ & $\begin{array}{l}-.050 \\
(.120)\end{array}$ & $\begin{array}{c}0.143^{* *} \\
(.071)\end{array}$ & $\begin{array}{c}.205 \\
(.166)\end{array}$ & $\begin{array}{c}0.129^{* * *} \\
(.031)\end{array}$ & $\begin{array}{l}.334^{* * *} \\
(.141)\end{array}$ \\
\hline Adj. R-squared & 0.091 & 0.178 & 0.194 & 0.026 & 0.102 & 0.291 & 0.268 & 0.246 \\
\hline Observations & \multicolumn{2}{|c|}{62} & \multicolumn{2}{|c|}{76} & \multicolumn{2}{|c|}{37} & \multicolumn{2}{|c|}{57} \\
\hline
\end{tabular}

The variables are real per capita stock market capitalization of category 1 firms and real per capita GDP. Each panel contains a different sub-period. In each sub-period we find one cointegration relationship at the $5 \%$ level or better. We assume a linear trend in the data, an intercept and no trend in the cointegration relationship. The VECM has 1 lagged differenced variable term in the estimation. Standard errors for the coefficient estimates are in parentheses. ${ }^{* * *}$ denotes significance at the 1 percent level, ${ }^{* *}$ at the 5 percent level and ${ }^{*}$ at the 10 percent level. 
Table 4: VECM Estimation for GDP and Stock Market Development Indicators.

\begin{tabular}{|l|c|c|c|c|}
\hline & Shares 1 & cum IPO & Intl Char & Concentr 3 \\
\hline$\beta$ & -.257 & .032 & -.621 & $-.851^{* * *}$ \\
& $(.922)$ & $(.033)$ & $(.500)$ & $(.199)$ \\
$\alpha_{Y}$ & $.021^{* * *}$ & $.018^{* * *}$ & $.024^{* * *}$ & $.010^{* * *}$ \\
& $(.010)$ & $(.004)$ & $(.005)$ & $(.003)$ \\
$\alpha_{F}$ & -.001 & -.014 & -.007 & $.087^{* * *}$ \\
& $(.001)$ & $(.009)$ & $(.008)$ & $(.018)$ \\
\hline
\end{tabular}

The variables are real per capita GDP, the number of listed shares of category 1 firms (multiplied by 100), the cumulative number of initial public offerings (multiplied by 1000), the number of total firms divided by the number of category 1 firms (multiplied by 100,000), and the share of the largest 3 firms in the total market capitalization (multiplied by 10,000). We assume a linear trend in the data, an intercept and no trend in the cointegration relationship. The VECM has 2 lagged differenced variable terms in the estimation, only the speed of adjustment coefficients are reported. The number of observations is 168 after adjusting the endpoints. Standard errors for the coefficient estimates are in parentheses. ${ }^{* * *}$ denotes significance at the 1 percent level, ${ }^{* *}$ at the 5 percent level and ${ }^{*}$ at the 10 percent level. 
Table 5: VECM Estimation for the Trivariate Model.

\begin{tabular}{|l|ccc|}
\hline Cointegrating Eq & \multicolumn{3}{|c|}{$1875-2002$} \\
\hline$\beta_{M K}$ & \multicolumn{3}{|c|}{$(.157$} \\
& \multicolumn{3}{|c|}{$.096)$} \\
$\beta_{B A N K}$ & \multicolumn{3}{|c|}{$(.295)$} \\
& \multicolumn{3}{|c|}{$\Delta 2^{* * *}$} \\
\hline VECM & $\Delta Y_{t}$ & $\Delta M K_{t}$ & $\Delta B A N K_{t}$ \\
\hline$\alpha_{i}$ & $.009^{* * *}$ & .127 & $.190^{* * *}$ \\
& $(.002)$ & $(.102)$ & $(.065)$ \\
$\Gamma_{i Y}$ & .144 & 3.016 & .110 \\
& $(.095)$ & $(4.092)$ & $(2.614)$ \\
$\Gamma_{i M K}$ & $.005^{* * *}$ & -.069 & .038 \\
& $(.002)$ & $(.096)$ & $(.061)$ \\
$\Gamma_{i B A N K}$ & $.008^{* *}$ & .238 & .083 \\
& $(.003)$ & $(.147)$ & $(.094)$ \\
\hline Adj. R-squared & 0.351 & 0.078 & 0.141 \\
\hline Observations & \multicolumn{3}{|c}{114} \\
\hline
\end{tabular}

The variables are real per capita GDP, real per capita market capitalization (category 1 firms, multiplied by 10), and real per capita savings plus deposits (multiplied by 10,000). We assume a linear trend in the data, an intercept and no trend in the cointegration relationship. The VECM has 1 lagged differenced variable term in the estimation, only the speed of adjustment coefficients are reported. The number of observations is 114 after adjusting the endpoints. Standard errors for the coefficient estimates are in parentheses. ${ }^{* * *}$ denotes significance at the 1 percent level, ** at the 5 percent level and ${ }^{*}$ at the 10 percent level. 


\section{References}

Annaert, Jan, Frans Buelens, Ludo Cuyvers, Marc De Ceuster, G. Devos, M. Gemis, Helma Houtman-De Smedt, and J. Paredaens, "Ontwerp van een Databank m.b.t. het Archief van de Beurs van Brussel en Antwerpen," 1998. Working Paper, Departement Toegepaste Economische Wetenschappen, RUCA.

Arestis, Phillip, Panicos Demetriades, and Kul Luintel, "Financial Development and Economic Growth: The Role of Stock Markets," Journal of Money, Credit and Banking, 2001, pp. 16-41.

Atje, Raymond and Boyan Jovanovic, "Stock Markets and Development," European Economic Review, 1993, pp. 632-640.

Bencivenga, Valerie and Bruce Smith, "Financial Intermediation and Endogenous Growth," Review of Economic Studies, 1991, pp. 195-209.

Boyd, John and E. Prescott, "Financial Intermediary Coalitions," Journal of Economic Theory, 1986, pp. 211-232.

Cameron, Rondo, Banking in the Early Stages of Industrialization: A Study in Comparative Economic History, New York: Oxford University Press, 1967.

Carlos, Ann and Stephen Nicholas, "Agency Problems in Early Chartered Companies: The Case of the Hudson Bay Company," Journal of Economic History, 1990, 50, 853-875.

Caulier-Mathy, N., The Economic Development of Belgium Since 1870, Cheltenham, UK: The Elgar Reference Collection, 1986.

Crafts, N.F.R., "Macroinventions, Economic Growth, and 'Industrial Revolution' in Britain and France," Economic History Review, 1995, pp. 591-598.

Cuyvers, Ludo and W. Meeusen, "The Structure of Personal Influence of the Belgian Holding Companies: A Quantitative Analysis," European Economic Review, 1976, 8, 51-69.

_ Press, 1985.

DeClercq, Guido, Ter Beurze: Geschiedenis van de Aandelenhandel in Belgie, 1300-1990, Antwerpen: Uitgeversbedrijf Tijd, 1992.

Demetriades, Panicos and Khaled Hussein, "Does Financial Development Cause Economic Growth? Time-series Evidence From 16 Countries.," Journal of Development Economics, 1996, 51, 387-411.

Diamond, Douglas, "Financial Intermediation and Delegated Monitoring," Review of Economic Studies, 1984, pp. 393-414.

and Philip Dybvig, "Bank Runs, Deposit Insurance, and Liquidity," Journal of Political Economy, 1983, (91), 401-419.

Goldsmith, Raymond, Financial Structure and Development, New Haven: Yale University Press, 1969. 
Greenwood, Jeremy and Bruce Smith, "Financial Markets in Development and the Development of Financial Markets," Journal of Economic Dynamics and Control, 1997, pp. 145-181.

Gregorio, Jose De and Pablo Guidotti, "Financial Development and Economic Growth," World development, 1995, 23, 433-448.

Gurley, John and Edward Shaw, "Financial Aspects of Economic Development," The American Economic Review, 1955, (45), 515-538.

Hansson, Pär and Lars Jonung, "Finance and Economic Growth: The Case of Sweden 1834-1991," Research in Economics, 1997, 51, 275-301.

Hicks, John, A Theory of Economic History, Clarendon Press, 1969.

Johansen, Soren and Katarina Juselius, "Maximum Likelihood Estimation and Inference on Cointegration with Applications to the Demand for Money," Oxford Bulletin of Economics and Statistics, May 1990, 52, 169-210.

King, Robert and Ross Levine, "Finance and Growth: Schumpeter Might be Right," Quarterly Journal of Economics, 1993, pp. 717-737.

Levine, Ross, "Financial Development and Economic Growth: Views and Agenda," Journal of Economic Literature, 1997, pp. 688-726.

- and Sarah Zervos, "Stock Markets, Banks, and Economic Growth," American Economic Review, June 1998

Maddison, Angus, Monitoring the World Economy, 1820-1992, Washington DC: OECD, 1995.

Mitchell, Brian, European Historical Statistics, 1750-1975, New York: Facts on File, 1980.

Obstfeld, Maurice, "Risk Taking, Global Diversification, and Growth," American Economic Review, 1994, pp. 1310-1329.

Patrick, Hugh, "Financial Development and Economic Growth in Underdeveloped Countries," Economic Development and Cultural Change, 1966.

Rousseau, Peter and Paul Wachtel, "Financial Intermediation and Economic Performance: Historical Evidence from Five Industrialized Countries," Journal of Money Credit and Banking, 1998, pp. 657-678.

_ and _ _ "Equity Markets and Growth: Cross-Country Evidence on Timing and Outcomes, 19801995," Journal of Banking and Finance, 2000, pp. 1933-1957.

_ and Richard Sylla, "Financial Systems, Economic Growth, and Globalization," 2001. Working Paper, NYU Stern.

_ _ and __ ,Emerging Financial Markets and Early U.S. Growth," Explorations of Economic History, 2005, 42, 1-26.

Stiglitz, Joseph, "Credit Markets and The Control of Capital," Journal of Money, Credit, and Banking, 1985, pp. 133-152. 
Townsend, Robert, "Optimal Contracts and Competitive Markets with Costly State Verification," Journal of Economic Theory, 1979, (21), 265-293.

Vandermotten, C., "Tendances longues de l'évolution de la production, de l'emploi et de la productivité industriels en Belgique 1840-1978," Cahiers Economiques de Bruxelles, 1980, (81), 261-301.

VanNieuwerburgh, Stijn, "The Relationship Between Financial Intermediation and Economic Growth in Developing Countries," Master's thesis, University of Gent May 1998.

Williamson, Steven, "Costly Monitoring, Financial Intermediation, and Equilibrium Credit Rationing," Journal of Monetary Economics, 1986, (18), 159-179.

\section{A Econometric Analysis}

This appendix provides the details of the econometric approach used in the main text.

Let $x$ and $y$ be variables that are integrated of degree one. To investigate the relation between the endogenous variable $y$ and the exogenous variable $x$ we start from the dynamic equation:

$$
y_{t}=\gamma_{0} x_{t}+\gamma_{1} x_{t-1}+\alpha y_{t-1}+\varepsilon_{t} .
$$

Denoting first differences by $\Delta$, rearranging equation (1) leads to the error correction form:

$$
\Delta y_{t}=\gamma_{0} \Delta x_{t}+(\alpha-1)\left(y_{t-1}-\beta x_{t-1}\right)+\varepsilon_{t},
$$

where

$$
\beta=\frac{\gamma_{0}+\gamma_{1}}{1-\alpha}
$$

The change in the dependent variable $\Delta y$ is decomposed into short-run dynamics captured by $\Delta x$, and long-term dynamics captured by the equilibrium relationship $y=\beta x$.

The cointegration analysis starts from a system of error correction equations, one for each variable under consideration. All variables of interest are endogenous. The data will determine which ones are exogenous, and hence speak to the direction of causality.

$$
\Delta Z_{t}=\Gamma_{1} \Delta Z_{t-1}+\ldots+\Gamma_{k-1} \Delta Z_{t-k+1}+\Pi Z_{t-1}+\mu+\Psi D_{t}+\varepsilon_{t}
$$

where $Z$ is a $p \times 1$ vector of endogenous variables, $\varepsilon$ is a $p \times 1$ vector of normally distributed errors, $D$ is a vector of exogenous variables to the system, $\Gamma_{i}$ are $(p \times p)$ matrices of short-term loadings, for lags $i=1, \ldots, k-1$ and $\Pi$ is the matrix of long-run loadings. We allow for a non-zero intercept $\mu$ in the cointegration relationship and a linear trend in the data.

Integrated variables of order 1 (non-stationary) are called cointegrated when a linear combination of them is integrated of order 0 (stationary). The rank $r$ of the matrix $\Pi$ determines the number of cointegration relationships. Let $\lambda_{1}, \lambda_{2}, \ldots, \lambda_{r}, \ldots, \lambda_{p}$ be the $p$ eigenvalues of $\Pi$. We use the full information maximum likelihood method (Johansen and Juselius (1990)) to determine how many cointegration relationships there are between the elements in $Z$. The algorithm works as follows. Starting with the hypothesis of $p$ unit roots, set $k=p$ and form the $\lambda^{\text {max }}$ and the $\lambda^{\text {trace }}$ 
statistic:

$$
\begin{aligned}
J^{\max } & =-T \log \left(1-\lambda_{k}\right), \\
J^{\text {trace }} & =-T \sum_{i=1}^{k} \log \left(1-\lambda_{i}\right),
\end{aligned}
$$

where $\mathrm{T}$ is the number of observations in the time-series. If the null hypothesis $H_{0}: \lambda_{1}=\lambda_{2}=\ldots=\lambda_{p}=0$ is rejected, $\lambda_{1}>0$. Set $k=p-1$ and test $H_{0}: \lambda_{2}=\lambda_{3}=\ldots=\lambda_{p}=0$. If again the null is rejected, $\lambda_{2}>0$. Proceed until the null can no longer be rejected. The number of cointegration relationships, or the reduced rank, is $r$ when the null hypothesis $H_{0}: \lambda_{r+1}=\lambda_{r+2}=\ldots=\lambda_{p}=0$ cannot be rejected.

The cointegration vectors are $\beta^{\prime} Z$, which we obtain by partitioning the matrix $\Pi=\alpha \beta^{\prime}$ into two $p \times r$ matrices of rank $r$ (Granger's representation theorem). The matrix $\alpha$ measures the speed of convergence towards the long-run equilibrium. The matrix $\beta$ contains the cointegration coefficients. The bivariate system of financial development (F) and economic activity (Y) with a single cointegration vector, becomes

$$
\begin{aligned}
\Delta F_{t} & =\Gamma_{F F} \Delta F_{t-1}+\Gamma_{F Y} \Delta Y_{t-1}+\alpha_{F}\left(\beta_{F} F_{t-1}+\beta_{Y} Y_{t-1}\right)+\mu_{F}+\varepsilon_{F t} \\
\Delta Y_{t} & =\Gamma_{Y F} \Delta F_{t-1}+\Gamma_{Y Y} \Delta Y_{t-1}+\alpha_{Y}\left(\beta_{F} F_{t-1}+\beta_{Y} Y_{t-1}\right)+\mu_{Y}+\varepsilon_{Y t}
\end{aligned}
$$

This is the system we estimate in the main text. 